Research Article

\title{
Anthelmintic activity of Cassia occidentalis $L$. methanolic leaf extract on Ascaridia galli and Heterakis gallinarum and its acute toxicity
}

\author{
John N. Kateregga*, Maria Nabayunga, Patrick Vudriko, James G. Ndukui
}

College of Veterinary Medicine, Animal Resources and Biosecurity, Makerere University, P.O. Box 7062, Kampala, Uganda

Received: 27 November 2013

Accepted: 15 December 2013

*Correspondence to:

Dr. John N. Kateregga,

Email: katereggaj@vetmed.mak.ac.ug

(C) 2014 Kateregga JN et al. This is an open-access article distributed under the terms of the Creative Commons Attribution Non-Commercial License, which permits unrestricted noncommercial use, distribution, and reproduction in any medium, provided the original work is properly cited.

\begin{abstract}
Background: Cassia occidentalis is traditionally used to treat helminth infestations in poultry. We investigated the in-vitro anthelmintic activity of the methanolic leaf extract of this plant against Heterakis gallinarum and Ascaridia galli worms and its acute toxicity.

Methods: Leaves of the plant were air dried, ground into powder and extracted with $70 \%$ methanol, filtered and dried at $50^{\circ} \mathrm{C}$ into a dark green semi-solid mass. The worms were isolated from fresh intestines of local chicken and pheasants or turkeys freshly slaughtered in Kampala markets. They were placed in conical flasks containing Goodwin's solution, kept in a water bath set at $39^{\circ} \mathrm{C}$ and exposed to $8,12,16,20$ and $24 \mathrm{mg} / \mathrm{ml}$ extract concentrations. Percent worm mortality was determined for each concentration at $12 \mathrm{~h}$ intervals. piperazine and ivermectin were used as positive controls. For acute toxicity evaluation, Swiss mice were divided into 5 groups $(n=6)$ and administered per os with extract doses of 5,000, $10,000,15,000,20,000$ and $25,000 \mathrm{mg} / \mathrm{Kg}$. The $\mathrm{EC}_{50}$ was determined by a plot of mortality probits against log extract concentration.

Results There was a concentration-dependent relationship with worm mortality. The mean worm mortality for A. galli was significantly higher for the extract than for piperazine at 16 and $20 \mathrm{mg} / \mathrm{ml}(\mathrm{p}<0.05)$ and 24 $\mathrm{mg} / \mathrm{ml}$ concentrations $(\mathrm{p}<0.01)$. Activity against $H$. gallinarum was not significantly different from that of ivermectin. The $\mathrm{EC}_{50}$ of the extract was $11.78 \mathrm{mg} / \mathrm{ml}$ for $A$. galli and $17.78 \mathrm{mg} / \mathrm{ml}$ for $H$. gallinarum. The extract is safe according to OECD acute toxicity guidelines since no mortality and toxicity signs were observed in mice even at $25,000 \mathrm{mg} / \mathrm{kg}$. Conclusions: The study demonstrated the anthelmintic activity of $C$. occidentalis and this could explain its use in traditional medicine as a remedy against helminth infections over the generations in many parts of Uganda.
\end{abstract}

Keywords: Cassia occidentalis, Heterakis gallinarum, Ascaridia galli, Anthelmintic activity, Acute toxicity

\section{INTRODUCTION}

Poultry is a major source of high quality protein for the fast growing human population and provides income to resource-poor small-scale rural farmers; especially women. ${ }^{1}$ Rural poultry require low levels of inputs and contribute significantly to food security and poverty alleviation. Chicken, which make up around $80 \%$ of poultry stocks in many developing countries of Africa and Asia, are also highly valued in the religious and socio-cultural lives of local communities and provide employment to many rural folk. ${ }^{2}$

Although global poultry meat production has increased in the last 10 years from $20 \%$ to $30 \%$, infections such as helminthosis remain a major constraint to rural poultry production. ${ }^{3,4}$ Free ranging poultry production systems which predominate in rural communities expose birds to 
heavy worm burdens. The most frequently diagnosed nematodes of poultry are Acaridia galli and Heterakis gallinarum, with prevalences of $51.6 \%$ and $31 \%$ in chicken and turkeys respectively. ${ }^{5}$ Heterakis gallinarum is estimated to cause production losses in a range $10 \%$ to $20 \%$ due to impaired feed conversion, reduced egg production and increased mortality. ${ }^{6}$ This nematode also plays a role in histomoniasis (black head disease) epidemiology in turkeys where it causes severe disease and high mortality, sometimes up to $100 \%$ of a flock. ${ }^{7,8}$ Ascaridia galli causes ascaridiosis with reduced feed conversion and mortality in birds.

The use of modern anthelmintics is not common among rural poultry farmers in developing countries because of high costs of drugs, their low availability and the high rates of illiteracy of the farmers. According to Uganda Bureau of Statistics (UBOS), 60.7\% of rural people live below the poverty line and cannot afford conventional drugs. ${ }^{9}$ Furthermore; there is limited availability of drugs in rural areas despite the helminth burden prevalent in these areas due to the free range production system practiced there. In addition, drug residue problems and the development of resistance by target parasites have made alternative remedies imperative. ${ }^{10,11}$ Cassia occidentalis has for long been used by rural communities in Uganda against both human and domestic animal helminth infestations and, in the Luganda language spoken in central Uganda, it is known as "Omutanjoka" ('worm killer'). Other studies indicate that the plant also possesses antibacterial, antiparasitic and antifungal effects. $^{12}$ Exploitation of medicine plants provides alternative disease control options that are culturally acceptable; ecologically and environmentally sound. ${ }^{13}$ This study sought to evaluate the anthelmintic properties of Cassia occidentalis leaves as well as its acute toxicity in mice.

\section{METHODS}

\section{Plant materials}

Fresh leaves from healthy Cassia occidentalis plants free from plant pests were collected in Uganda from Nakabago village $\left(0^{\circ} 24^{\prime}\right.$ North $32^{\circ} 42^{\prime}$ East, VR 67,34$)$ and dried in the oven at $50^{\circ} \mathrm{C}$ for two days to a constant weight. A mature branch with flowers and fruits was picked from a plant and dried between plant presses under direct sunlight. The plant was identified, authenticated and a voucher specimen Maria Nabayunga No. 1 was deposited at the Botany Herbarium of Makerere University.

\section{Preparation of the extract}

The cold maceration method was used for extraction. Dried leaves were thoroughly crushed using motor and pestle and $350 \mathrm{~g}$ of the powder was soaked in two liters of $70 \%$ methanol in a brown bottle at $25^{\circ} \mathrm{C}$ for three days and kept in a wooden cabinet. The mixture was shaken periodically and then filtered using cotton wool. The filtrate was poured in labeled kidney dishes of known weight and dried off in the oven at $50^{\circ} \mathrm{C}$ for two days, leaving a dark green residue which was weighed and placed in a glass bottle and kept at $4^{\circ} \mathrm{C}$ for further use. A stock solution of the extract was prepared immediately with distilled water before the start of the anthelmintic or acute toxicity evaluation experiments.

\section{Worm collection}

Ascaridia galli worms were collected from the small intestines of freshly killed indigenous chicken from a chicken slaughter house in Bwaise market, Kampala, while Heterakis gallinarum worms were collected from the caeca of freshly slaughtered turkeys. Intestines and caeca were then dissected and worms isolated while placing them into a vacuum flask containing Goodwin's physiological solution before being transported to the lab. They were then placed in two separate glass beakers containing Goodwin's physiological solution and kep at $37^{\circ} \mathrm{C}$ immediately.

\section{Evaluation of anthelmintic activity}

The worms were placed in $250 \mathrm{ml}$ conical flasks containing $100 \mathrm{ml}$ of Goodwin's solution at $37^{\circ} \mathrm{C}$ with each flask having 6 worms. For each worm species, 5 extract concentrations of $8,12,16,20$ and $24 \mathrm{mg} / \mathrm{ml}$ were used in duplicates. The negative control was Goodwin's solution with no extract added. Piperazine citrate $(2 \mathrm{mg} / \mathrm{ml})$ was used as positive control for Ascaridia galli while ivermectin $(0.5 \mathrm{mg} / \mathrm{ml})$ was used for Heterakis gallinarum. The extract concentrations were prepared from the stock solution using the formula $C_{1} V_{1}=C_{2} V_{2}$ where $C_{1}$ was the extract concentration; $C_{2}$ was the stock concentration; $\mathrm{V}_{1}$ was the volume of Goodwin's solution in each flask and $\mathrm{V}_{2}$ was the volume of the stock solution to be added to each flask.

The experimental setups for the two worm species were carried out separately in a water bath at $39^{\circ} \mathrm{C}$ for $\mathrm{A}$. galli and at $41^{\circ} \mathrm{C}$ for $H$. gallinarum. The worms were then observed for mortality at time intervals of 12, 24, 36 and 48 hours and were recorded as dead when they did not express sinusoidal movement upon exposure of their extreme ends to a water temperature of $50^{\circ} \mathrm{C}$. The number of dead and live worms for each flask were recorded and mean mortality \pm SEM was calculated from the duplicates. Percent mortality for each concentration was determined and mean half-maximal effective concentration $\left(\mathrm{EC}_{50}\right)$ obtained from a plot of percent mortality versus log concentration using GraphPad Prism. ANOVA was used for statistical comparison of mortality for the different extract concentrations. The differences were considered significant at $\mathrm{p}<0.05$ or $\mathrm{p}<0.01$.

\section{Evaluation of the acute toxicity of the extract}

Swiss mice aged 6-7 weeks old and weighing 20-29g were used for the acute toxicity study. They were fed on mice feed and water was provided ad libitum. Before the 
experiment they were allowed to acclimatize for two weeks. The staircase (up and down) method was used to determine the different doses to be used for the different mice groups during the acute toxicity study. ${ }^{14}$ Two mice were randomly selected and orally administered with a limit dose of $5000 \mathrm{mg} / \mathrm{kg}$ of the extract using an intragastric tube and observed for mortality after 24 hours. Basing on the results of the preliminary investigation, doses of 5,000, 10,000, 15,000, 20,000 and $25,000 \mathrm{mg} / \mathrm{Kg}$ were used in the actual study.

Thirty (30) mice were placed in 5 groups of six mice each i.e. three females and three males with separate cages for each sex. The animals were fasted for 3 hours before the experiment and were weighed before dosing. They were then marked with unique marks on the tails using a water proof marker for proper identification and follow up during the experiment. Group 1 was used as a negative control and no extract was administered to this group. Group II to IV were orally administered with the extract using an intragastric tube at doses of 5,000, 10,000, $15,000,20,000$ and $25,000 \mathrm{mg} / \mathrm{Kg}$ respectively. The volume of stock solution for oral dosing was calculated using the formula $V=\frac{\mathrm{DxW}}{\mathrm{C}}$; where $\mathrm{V}(\mathrm{ml})$ is volume required from the stock solution; $\mathrm{D}(\mathrm{mg} / \mathrm{kg})$ is the dose; $\mathrm{W}(\mathrm{kg})$ is mouse body weight and $\mathrm{C}(\mathrm{mg} / \mathrm{ml})$ is stock solution concentration. ${ }^{15}$ The number of dead animals per group after 24 hours was recorded. Determination of the $\mathrm{LD}_{50}$ was done by plotting mortality probits against $\log$ dose. ${ }^{16}$ Ethical clearance was obtained from the Research and Ethics Committee of the College of Veterinary Medicine, Makerere University.

\section{RESULTS}

The ascaricidal activity of the $C$. occidentalis methanolic extract increased with incubation time (Figure 1). After 12 hours, only the positive control showed mortality. The $8,12,16,20$, and $24 \mathrm{mg} / \mathrm{ml}$ concentrations showed mortality after 24 hours. The negative control did not show any mortality up to 48 hours. At 48 hours the 24 $\mathrm{mg} / \mathrm{ml}$ concentration showed a significantly higher mortality $(\mathrm{p}<0.01)$ than the positive control (piperazine citrate) when used at the recommended concentration of $2 \mathrm{mg} / \mathrm{ml}$ (Table 1). No mortality was observed for the negative control.

The anti-Heterakis gallinarum activity of the extract increased with duration of incubation time (Figure 2). Only the 16 and $24 \mathrm{mg} / \mathrm{ml}$ extract concentrations and positive control showed mortality after 12 hours. The $24 \mathrm{mg} / \mathrm{ml}$ showed higher mortality than the positive control (Table 2) but this was not statistically significant ( $>0.05)$. No mortality was observed for the negative control.

The C. occidentalis methanolic extract showed a concentration-dependent relationship on both A. galli and H. gallinarum nematodes.

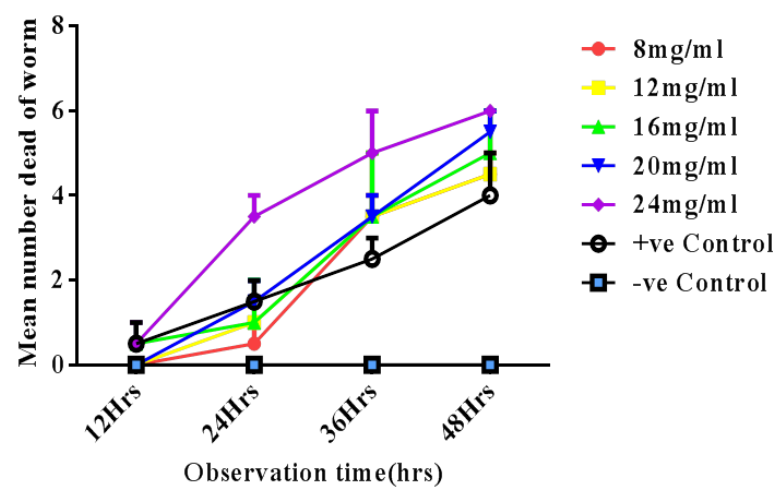

Figure 1: Effect of Cassia occidentalis methanolic leaf extract on Ascaridia galli.

The worms were exposed to various concentrations of the $C$. occidentalis methanolic extract for a period of 48 hours. The extract showed a concentration and time-dependent wormicial activity.

Table 1: Ascaridia galli mortality at $\mathbf{4 8 h}$ for the different treatments.

\begin{tabular}{|lll|}
\hline Treatment & $\begin{array}{l}\text { Mean mortality } \\
\text { SEM }\end{array}$ & $\begin{array}{l}\% \\
\text { mortality }\end{array}$ \\
\hline Extract $8 \mathrm{mg} / \mathrm{ml}$ & $2.00 \pm 0.91$ & 33.3 \\
\hline Extract $12 \mathrm{mg} / \mathrm{ml}$ & $2.63 \pm 1.14$ & 50.0 \\
\hline Extract $16 \mathrm{mg} / \mathrm{ml}$ & $2.75 \pm 1.20^{*}$ & 66.7 \\
\hline Extract $20 \mathrm{mg} / \mathrm{ml}$ & $3.00 \pm 1.34^{*}$ & 66.7 \\
\hline Extract $24 \mathrm{mg} / \mathrm{ml}$ & $3.50 \pm 1.24^{* *}$ & 83.3 \\
\hline $\begin{array}{l}\text { Piperazine } 2 \mathrm{mg} / \mathrm{ml} \\
\text { (Positive control) }\end{array}$ & $2.25 \pm 0.52$ & 33.3 \\
\hline $\begin{array}{l}\text { Goodwin's solution } \\
\text { (Negative control) }\end{array}$ & $0.0 \pm 0.0$ & 0.0 \\
\hline
\end{tabular}

$\mathrm{n}=6, \quad \mathrm{p}<0.05, \quad{ }^{* *} \mathrm{p}<0.01$ (comparison of concentrations with positive control)

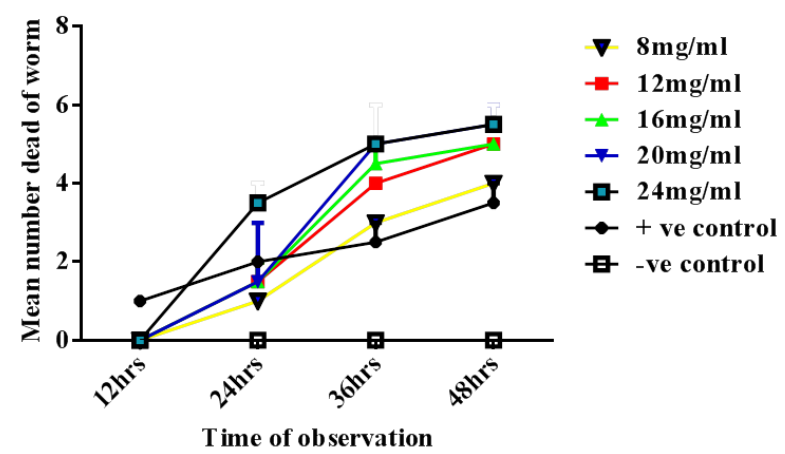

\section{Figure 2: Effect of Cassia occidentalis on Heterakis} gallinarum.

The worms were exposed to various concentrations of the test extract. The extract showed a concentration and time-dependent wormicial activity.

However, the mortality was higher for A. galli than for $H$. gallinarum especially at the higher doses (Figure 3 ). The 
$\mathrm{R}$ (regression co-efficient) for A. galli was 0.8891 while that for $H$. gallinarum was 0.7814 indicating a stronger relationship between dose and response for A. galli. The $\mathrm{EC}_{50}$ for the $A$. galli was determined to be $11.78 \mathrm{mg} / \mathrm{ml}$ while that for $H$. gallinarum was $17.75 \mathrm{mg} / \mathrm{ml}$.

\section{Table 2: Heterakis gallinarum mortality at $48 \mathrm{~h}$ for the} different treatments.

\begin{tabular}{|lll|}
\hline Treatment & $\begin{array}{l}\text { Mean mortality } \pm \\
\text { SEM }\end{array}$ & $\begin{array}{l}\% \\
\text { mortality }\end{array}$ \\
\hline Extract $8 \mathrm{mg} / \mathrm{ml}$ & $2.13 \pm 1.11$ & 33.3 \\
\hline Extract $12 \mathrm{mg} / \mathrm{ml}$ & $2.25 \pm 1.05$ & 33.3 \\
\hline Extract $16 \mathrm{mg} / \mathrm{ml}$ & $2.50 \pm 1.06$ & 50.0 \\
\hline Extract $20 \mathrm{mg} / \mathrm{ml}$ & $2.63 \pm 1.197$ & 50.0 \\
\hline Extract $24 \mathrm{mg} / \mathrm{ml}$ & $3.75 \pm 1.20$ & 66.7 \\
\hline $\begin{array}{l}\text { Ivermectin } \\
0.5 \mathrm{mg} / \mathrm{ml}(\text { Positive } \\
\text { control) }\end{array}$ & $2.13 \pm 0.75$ & 33.3 \\
\hline $\begin{array}{l}\text { Goodwin's solution } \\
\text { (Negative control) }\end{array}$ & $0.0 \pm 0.0$ & 0.0 \\
\hline
\end{tabular}

$\mathrm{n}=6, \mathrm{p}>0.05$ (comparison of concentrations and positive control)

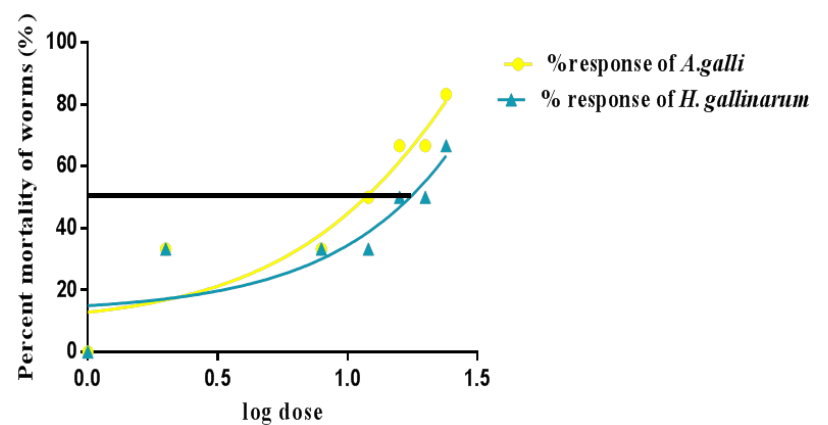

Figure 3: Concentration-response relationship for $A$. galli and $\boldsymbol{H}$. gallinarum.

The $\mathrm{EC}_{50}$ of the extract for A. galli and H. gallinarum is the anti-log of the value on the $\mathrm{x}$ axis corresponding to $50 \%$ mortality.

\section{DISCUSSION}

Rural poultry farmers in Uganda use both modern anthelmintics and medicinal plants to control Ascaridia galli and Heterakis gallinarum infestations. Piperazine, the standard drug for $A$. galli acts by increasing chloride ion conductance leading to hyperpolarisation of the worm muscles leading to paralysis and death of the worm. ${ }^{17}$ Ivermectin, the drug mainly used for $H$. gallinarum binds selectively to glutamate-gated chloride ion channels in worm nerve and muscle cells causing hyperpolarization of the cells and paralysis and death of the worms. It is believed to act as an agonist at the receptor of the inhibitory neurotransmitter GABA, disrupting GABAmediated central nervous system neurosynaptic transmission. ${ }^{18}$

This study demonstrated that $C$. occidentalis extracts have incubation time and concentration-dependent anthelmintic activity against both worms. The dose-dependent relationship could be explained by exposure of the worms to higher quantities of the ascaricidal components of the plant extract leading to higher mortalities. The increase in activity with time may be due to a higher number of receptor sites being occupied by the active ingredients of the extract with increase in incubation time. ${ }^{19}$ An in vitro study with the ethanolic leaf extract of $C$. occidentalis show ascaricidal activity against $A$. suum another worm of the Ascarididae family. ${ }^{20}$

The nematocidal activity of the plant could be attributed to phytochemicals in the leaves. The main phytochemicals in $C$. occidentalis leaf are carbohydrates, saponins, flavonoids, terpenes, sterols, alkaloids, anthraquinones and tannins. ${ }^{21}$ The methanolic leaf extract of this plant has been shown to have high quantities of tannins, saponins and alkaloids; ${ }^{22}$ phytochemicals with demonstrated anthelmintic properties. ${ }^{23}$ Tannins are water soluble polyphenolic compounds which interfere with energy generation in helminths by uncoupling oxidative phosphorylation just like synthetic phenolic anthelmintics like niclosamide, oxyclozamide, nitroxynil and bithionol and could have been majorly responsible for the activity observed in this study. ${ }^{24}$ They also bind free proteins in the gastrointestinal tract of the host or glycolprotein on the cuticle of the parasite disrupting the physiological functions such as motility, feed absorption and reproduction. $^{25,26}$ They also cause death by interfering with the morphology and disrupt the proteolytic activity of microbes. ${ }^{27}$

Alkaloids could have contributed to the paralysis and consequent death of the worms. The nematocidal activity of alkaloids has been demonstrated in two rat nematodes; Strongyloides ratti and Strongyloides venezuelensis. ${ }^{28}$ Alkaloid salts are competitive antagonists at muscarinic cholinergic receptor preventing the binding of acetylcholine and their activity is similar to that of some anthelmintics such as pyrantel and morantel. ${ }^{29}$ Saponins are known to cause feed refusal and starvation of the parasites leading to their death from lack of energy. Such metabolites may work singly or in combination to impair worm motility (paralysis) and or cause death of the helminths. The synergistic interactions of the phytochemicals have been shown to be more effective than activity of individual constituents. ${ }^{30}$ Plant metabolites' action may be additive, synergic, or antagonistic as they act at single or multiple target sites of the worms. ${ }^{31}$

The acute toxicity study showed no mortality up to the extract dose level of $25,000 \mathrm{mg} / \mathrm{kg}$ body weight. This indicates a high safety level since; according to OECD acute toxicity guidelines 423, doses higher than 5,000 $\mathrm{mg} / \mathrm{Kg}$ are assumed to be experimentally safe. ${ }^{32}$ This study has demonstrated the anthelmintic activity of $C$. occidentalis and this could explain its use in traditional medicine as a remedy against helminth infections over the generations in many parts of Uganda. There is however 
need to purify the crude extract further in order to identify the active chemicals responsible for the anthelmintic activity.

\section{Funding: No funding sources}

Conflict of interest: None declared

Ethical approval: Ethical clearance was obtained from the Research and Ethics Committee of the College of Veterinary Medicine, Makerere University

\section{ACKNOWLEDGEMENTS}

We thank the staff of the Pharmacology and Toxicology Laboratory of the College of Veterinary Medicine, Animal Resources and Biosecurity of Makerere University for their assistance during the laboratory experiments.

\section{REFERENCES}

1. Guèye EF. Family poultry research and development in low-income food-deficit countries: approaches and prospects. Outlook on Agriculture. 2002;31:13-21.

2. Pym RAE, Guerne BE Hoffmann I. The relative contribution of indigenous chicken breeds to poultry meat and egg production and consumption in the developing countries of Africa and Asia. Proceedings XII European Poultry Conference. EPC Verona, Italy: CD-ROM; September 2006: 10-14.

3. Alabi OJ, Ngambi JW, Norris D Mabelebele M. Effect of egg weight on hatchability and subsequent performance of Potchefstroom Koekoek chicks. Asian J. Anim. Vet Adv. 2012;7:718-25.

4. Njagi LW, Nyaga PN, Mbuthia PG, Bebora LC, Michieka JN, Kibe JK, Minga UM. Prevalence of Newcastle disease virus in village indigenous chickens in varied agro-ecological zones in Kenya. Livest Res Rural Dev. 2010;22:95

5. Matur BM. Prevalence of some gastrointestinal parasites in pullets of chickens (Gallus gallus domestica) in the Federal Capital Territory Abuja, Nigeria Journal of tropical Biosciences. 2002;2:7882.

6. Seddiek SHA, Mobarak MA, Mobarak AA. The effect of Artemisia herba alba on chickens infested with Ascaridia galli in comparison with piperazine citrate. Mansura Vet Med J. 2007;9:165-78.

7. Papini R, Caccuittolo E. Observations on the occurrence of Heterakis gallinarum in laying hens kept on soil. Ital. J Anim Sci. 2008;7:487-93.

8. McDougald LR. Blackhead Disease (Histomoniasis) in Poultry: A Critical Review. Avian Diseases. 2005;49: 462-476.

9. UBOS. Uganda National Household Survey by the Uganda Bureau of Statistics. Report on the SocioEconomic Model 2005/2006.

10. Murray VS, Wiseman HH, Dawlings S, Morgan I Housemann IM. Health effect of organophosphate sheep dips. British Veterinary Journal. 1992;305:1090-8.
11. Maingi NH, Bjorn SM, Tharmsborg HO, Bogh P, Nansen J. A survey of anthelmintic resistance in nematode parasites of goats in Denmark. Vet. Parasitol. 1996;66:53-66.

12. Yadav JP, Arya V, Yadav S, Panghal M, Kumar S, Dhankhar S. Cassia occidentalis: A review on its ethnobotany, phytochemical and pharmacological process. 2010Jun;81(4):223-30. Fitoterapia, doi:10.1016/j.fitote.2009.09.008.

13. Nalule AS, Mbaria JM, Olila D, Kimenju JW. Ethnopharmacological practices in management of livestock helminthes by pastoral communities in the drylands of Uganda. Livestock Research for Rural Development. 2011;23:6.

14. Choi SC. Interval estimation of the $\mathrm{LD}_{50}$ based on an up-and-down experiment. Biometrics. 1990;46:48592

15. Tedong L, Dzeufiet PDD, Dimo T, Asongalem, EA, Sokeng SN, Flejou JF, Callard P, Kamtchouing P. Acute and subchronic toxicity of Anacardium occidentale Linn (Anacardiaceae) leaves hexane extract in mice. Afr. J. Traditional Alternative Med. 2007;4:140-7.

16. Ogwal-Okeng JW, Obua C, Anokbonggo WW. Acute Toxicity Effects of Methanolic Extract of Fagara chalybeum Root Bark. African Health Sciences. 2003;3:124-126.

17. Del Castillo J, De Mello WC, Morales T. Mechanism of the paralysing action of Piperazine on ascaris muscle Brit J Pharmacol. 1964;22:463-77.

18. Imming $\mathrm{P}$, Sinning $\mathrm{C}$, Meyer A. Drugs, their targets and the nature and number of drug targets. Nat Rev Drug Discov. 2006;5:821-34.

19. Lullman H, Morh K, Bieger D. Colour Atlas of Pharmacology. New York: Theme Medical Publishers, Inc;1993: 52-98.

20. Wasswa P, Olila D. The in-vitro ascaricidal activity of selected indigenous medicinal plants used in ethno veterinary practices in Uganda. Afr $\mathrm{J}$ Traditional Alternative Med. 2006;3:94-103.

21. Muyibi SA, Olorode BR, Onyeyili PA, Osunkwo UA. Muhammad BY, Ajagbonna OP. Haematological and histopathological changes of Cassia occidentalis leaf extract in rats. Nig J Nat Prod Med. 2000;4:48-51.

22. Makut MD, Gyar SD, Pennap GRI, Anthony D. Phytochemical screening and antimicrobial activity of ethanolic and methanolic extracts of leaf and bark of Khaya senegalensis. African Journal of Biotechnology. 2008;7:1216-9.

23. Prashant T, Bimlesh K, Mandeep K, Gurpreet K, Harleen K. Phytochemical screening and Extraction. Internationale Pharmaceutica Sciencia. 2011;1:98106.

24. Martin RJ. Modes of action of anthelmintic drugs. The Veterinary Journal. 1997;154:11-34.

25. Hoste H, Jackson F, Athanasiadou S, Thamsborg SM Hoskin SO. The effects of tannin-rich plants on parasitic nematodes in ruminants. Trends in Parasitology. 2006;22:253-61. 
26. Githiori JB, Athanasiadou S, Thamsborg SM. Use of plants in novel approaches for control of gastrointestinal helminths in livestock with emphasis on small ruminants. Veterinary Parasitology 2006;139:308-20.

27. Min BR, Barry TN, Attwood GT, McNabb WC. The effect of condensed tannins on the nutrition and health of ruminants fed fresh temperate forages: a review. Animal Feed Science and Technology 2003;106:3-19.

28. Satou T, Koga M, Matsuhashi R, Koike K, Tada I Nikaido T. Assay of nematocidal activity of isoquinoline alkaloids using third stage larvae of Strongyloides ratti and $S$. venezuelensis. Veterinary Parasitology. 2002;104:131-8.

29. Tarnopolsky MA, Beal MF. Potential for creatine and other therapies targeting cellular energy dysfunction in neurological disorders. Annals of Neurology. 2001;49:561-74.

30. Kaufmann J. Parasitic Infections of Domestic Animals: A Diagnostic Manual. Switzerland: Birkhauser Verlag AG, Basel; 1996: 423.

31. Wynn SG, Fougere BJ. Introduction: Why use herbal medicine. In: Wynn SG, Fougere (Ed). Veterinary Herbal medicine: Library of Congress cataloging-in publication data; 2007: 695. ISBN: 10:0-323029981.

32. OECD. Organization of Economic Co-operation and Development guidelines for testing chemicals. 2001.

doi:10.5455/2319-2003.ijbcp20140213

Cite this article as: Kateregga JN, Nabayunga M, Vudriko P, Ndukui JG. Anthelmintic activity of Cassia occidentalis $L$. methanolic leaf extract on Ascaridia galli and Heterakis gallinarum and its acute toxicity. Int J Basic Clin Pharmacol 2014;3:114-9. 